\title{
TRB2 Bölgesi Turizminin Rekabet Gücü Üzerine Bir Alan Araştırması
}

\author{
Faruk Alaeddinoğlu $\mathrm{a}^{\mathrm{a}}$, Meryem Samırkaş Komşu ${ }^{\mathrm{b}}$ \\ "Van Yüzüncü Yıl Üniversitesi, Edebiyat Fakültesi, Coğrafya Bölümü, Van. \\ ${ }^{b}$ Mersin Üniversitesi, Erdemli Uygulamalı Teknoloji ve İsletmecilik Yüksekokulu, Mersin

\section{$\ddot{O} z$} \\ Bölgesel kalkınmada turizmi bir değişim ve kalkınma aracı olarak gören merkezi \\ yöneticiler, yerel yöneticiler ve turizm karar vericiler, illeri de bu değiskenler üzerinden rekabet \\ sürecine dâhil etmişlerdir. Bu süreç illerin veya daha büyük ölçüde bölgelerin turizme konu olan \\ kaynakların rakip bölgelere göre konumlamasını ve değerler üzerinden pazarlanmasın \\ sağlamıştır. Şüphesiz bu stratejinin başarılı olmasında ulusal ve uluslararası konjonktürün payı \\ olsa da, asıl belirleyici ve yönlendirici etki yerel dinamiklerle ilgilidir. Ancak mevcut dinamiklerin \\ turizm karar vericiler tarafindan nasıl görüldü̆g̈ü ve algılandığı bilgisi önemlidir. Bu bağlamda, \\ turizm sektöründe hizmet veren işletmelerin var olan durumu nasıl gördüklerinin ölçülmesi \\ gerekmektedir. Bu amaçla, TRB 2 bölgesi olarak adlandırılan Bitlis, Hakkâri, Muş ve Van illerinde \\ bir alan çalışması gerçekleştirmiştir. 13 çoktan seçmeli ve 34 Likert (5'li) yöntemine göre \\ hazırlanan anket sorusu, turizm sektöründe hizmet veren 260 işletme çalışanına uygulanmıştır. \\ Gerçekleştirilen çalışmada denekler, iller düzeyinde rekabet edebilirlik konusunda farkllliklar \\ olduğunu ortaya koyarken, genel anlamda turizme konu olan değerlerde üstün oldukların, ancak \\ altyapı, ulaşılabilirlik, ulusal kırılganliklar ve bölgesel sorunlar noktasında rekabet edebilme \\ düzeylerinin yetersiz oldukların ifade etmişlerdir. Bölgesel düzeyde gerçekleştirilen ve turizmde \\ rekabet düzeyini TRB2 bölgesinde ölçmeyi amaçlayan ilk araştırma olması nedeniyle özgün bir \\ çalışmadır.
}

Anahtar Kelimeler: Turizm Sektörü, TRB2 Bölgesi, Rekabet

\section{A Field Study on Competitiveness of Tourism in TRB2 Region}

\section{Abstract}

Public managers, local authorities and tourism decision makers who have considered tourism as a change and development tool in regional development, have also included the cities in the process of competition. This process has ensured the cities or regions to position and market touristic resources according their competitors. Surely, even though national and international conjuncture have a share in the success of this strategy, the main determinant is related to the local dynamics. However, the information of how the current dynamics are perceived by tourism decision makers is important. In this context, it is essential to find out how tourism enterprises evaluate the current situation. For this purpose, a field study conducted in Bitlis, Hakkari, Muş and Van cities which is called TRB 2 region. The questionnaire consists of 13 multiple choice questions and 34 Likert scale proposals has been applied on 260 employees working in tourism sector. The study shows that there are differences about the competitiveness at the city level and are generally good about the touristic values that are the subject of tourism. However they stated that the level of competitiveness about infrastructure, accessibility, national fragility and regional problems is insufficient. It is an original study as it is conducted at regional level and it aims to measure the level of competition in tourism industry in TBR2 region.

Keywords: Tourism Sector, TRB2 Region, Competition 


\section{GİRIŞ}

Turizm olgusu, yarattığı ekonomik etkiler nedeniyle başladığı günden bu yana ilerleyerek gelişmiş ve daha büyük ölçüde bölgelerin sürekli bir rekabet içerisinde olmasına neden olmuştur. Diğer sektörlerden farklı olarak müşterinin bizzat deneyimleyerek gerçekleştirdiği bir hizmet olan turizm, bir milyarın üzerinde turist ve bir trilyonun doların üzerinde gelirin elde edildiği muazzam bir endüstridir. Yaşanan bütün olumsuzluklara ve krizlere rağmen gelişmesini her dönem sürdürmüş ve birçok ülke, bölge ve ilin ilgisini çekmiş olan turizm, ekonomik büyüme ve sosyal gelişmenin en önemli argümanlarından biri haline gelmiştir. Bu büyük pastadan pay alabilmek veya mevcut payını geliştirmek için gelişmiş ya da gelişmekte olan bütün ülke, bölge ve iller büyük rekabet içerisine girmişlerdir. Dolayısıyla mevcut kaynaklarını etkin ve verimli şekilde kullanmak isteyen bütün turizm bölgeleri, belli ölçülerde partnerlik yapsalar da büyük ölçüde rakiptirler. Turizm ve daha birçok sektör için önemli olan rekabet kavramı, teknolojik gelişme, yenilik yapma, kaynakların verimli ve etkin kullanılmasını sağlama açısından itici güç ve (Aktan ve Vural, 2004: 1) iktisat kuramının en önemli kavramlarından biridir. Adam Smith'dan beri birçok iktisatçı tarafından ekonomik yaşamın düzenleyicisi olarak görülmüş ve ekonomik analizlerin temel ölçüsü kabul edilmiştir (Çapoğlu, 1993: 5). Ancak rekabet ve buna bağlı olarak rekabet gücü kavramlarının üzerinde iktisatçıların görüş birliğine vardıkları evrensel ve kesin bir tanım mevcut değildir. Bunun nedenleri ise; rekabet kavramı ve rekabet gücü, ele alınmak istenen alana göre değişmektedir. Örneğin rekabet gücü, firma, sektör ve ülke bazında değişmektedir. Diğer bir etken ise, rekabet bakış açısına göre farklılıklar gösterebilir. Rekabet kavramı mikro ve makro açıdan incelenebilinir. Başka bir ifadeyle, rekabet gücü firma düzeyinde, endüstri düzeyinde ve ulusal düzeyde tanımlanabilinir (Düzgün, 2007: 423).

Kökenin çok eskilere dayandığı bilinen rekabet kavramı, özellikle son yıllarda küreselleşme ile birlikte ülkeler arasındaki sınırların hızla ortadan kalkması ve ulaşım alanıyla iletişim alanındaki teknolojik gelişmelerin hızlanması rekabetçilik olgusunu her alanda olduğu gibi turizm sektöründe de her zamankinden daha önemli hale getirmiştir. 1950'li yıllardan sonra Dünya GSMH'dan daha hızlı bir gelişmeye sahip olan uluslararası turizm sektörü, gelişmiş ve gelişmekte olan birçok ülkede döviz kazandırıcı, yabancı sermayeyi teşvik edici, istihdam arttırıcı özellikleri ile ekonomik büyümenin ve gelişmenin en önemli kaynaklarından biri olarak görülmektedir (Samırkaş ve Bahar, 2011: 86).

Dünyanın en büyük üç hizmet sektöründen biri durumunda olan turizm sektöründe ülkelerin paylarını arttırma çabaları turizm rekabetini doğurmakta ve yeni destinasyonlar ile ürünlerin ortaya çıkmasına neden olmaktadır. Günümüzde turizm, bir sektör olarak uygun potansiyele sahip ülkelerin ekonomilerine önemli katkıda bulunmaktadır. Bu nedenle, birçok ülke ekonomik büyüme ve kalkınmaları için gerekli olan döviz girdisini sağlamak, yeni istihdam olanakları oluşturmak, pazar payını ve milli gelirini arttırmak amacıyla uluslararası turizm piyasasında birbirleri ile rekabet içindedirler (Bahar, 2004: 64). Ayrıca ülkeler, ulusal düzeydeki ekonomik ve sosyal hedeflerine ulaşmak için ulusal ekonominin yapı taşları olarak görülen 
bölgelerin rekabetçi ve dinamik olması gerektiğini vurgulamakta ve rekabet edebilirliğin artırılması bölgesel ekonomik politikanın en önemli hedefi olarak ortaya konmaktadır (Boschma, 2004: 1002).

Bölgesel kalkınmanın sağlanması ve bölgelere rekabetçi olma özelliği kazandıran en önemli sektörlerden birisinin "turizm" olduğu kabul edilmektedir. Turizm sektörü, ülkelerin veya bölgelerin sahip oldukları turizm arz kaynaklarını etkin bir şekilde kullanarak bölgesel kalkınmada önemli bir yere sahiptir. Türkiye açısından bir değerlendirme yapıldığında, ülkenin tabii güzelliklere ve tarihi zenginliklere sahip bölgeleri; genellikle sanayileşmenin hız kazandığ yamaçlarında, arkeolojik kazıların bulunduğu yerlerde veya göl kenarlarında bulunmaktadır. Ancak bu bölgeler genellikle turizm sektöründen yeterince faydalanamamaktadır. Türkiye'deki bölgeler arasında ekonomik ve sosyal kriterler açısından görülen büyük farklılıklar turizm göstergeleri açısından da görülmektedir.

Çalışma konusu olan Bitlis, Hakkari, Muş ve Van'ı kapsayan TRB2 bölgesi Türkiye'de diğer bölgelere göre gelişmişlik farkının en çok olduğu bölgedir. İllerin ve bölgelerin sosyo-ekonomik gelişmişlik sıralamasına göre düzey 2 kapsamında, 26 bölge içerisinde son sırada yer almaktadır. Bölgenin sosyo ekonomik anlamda görülen az gelişmişliği turizm göstergeleri açısından da kendini göstermektedir. Bu bağlamda bu çalışmanın amacı TRB2 bölgesini hem turizm göstergeleri hem de turizm işletmeleri gözüyle rekabet gücünü ortaya koymak ve sahip olduğu doğal, kültürel ve tarihi varlıkları değerlendirmesi noktasında önerilerde bulunmaktır.

Çalışma altı bölümden oluşturulmuştur. Giriş bölümünü takip eden ikinci bölümde rekabet ve turizm konusundaki literatür hakkında kısaca bilgi verilmiştir. Üçüncü bölümde ise, TRB2 bölgesinin sosyo-ekonomik yapısı ve turizm arz kaynakları açısından kısa bir değerlendirme yapılmıştır. Dördüncü bölümde çalışmada kullanılan yöntem tanıtılmıştır ve bunu takip eden beşinci bölümde, araştırma bulgularına yer verilmiştir. Altıncı bölümde ise çalışmanın sonuçları özetlenmiş ve değerlendirmeler yapılmıştır.

\section{LITERATÜR TARAMASI}

Rekabet kavramının incelenmesi ve çalışmalara konu olması iktisat ve pazarlama literatürünün geçmişi kadar uzun olmak birlikte, bu alandaki en önemli çalışma Michael Porter tarafından geliştirilen ve 1990 yılında yayınlanan "Ulusların Rekabet Üstünlüğü" çalışmasıdır. Porter bu çalışmayı rekabet gücü yüksek on ülkenin verilerine dayanarak, geniş bir araştırma grubu ile dört yıllık bir çalışma sonucu ortaya çıkarmıştır. Porter'ın amacı, ne bir teoriyi ispatlamaya ne de çürütmeye yöneliktir. Amaç; rekabet gücünü açıklama konusunda, geleneksel karşılaştırmalı üstünlükler teorisinin ötesinde bir açıklama sunabilmektir. Bir ülkenin sahip olduğu karşılaştırmalı üstünlük zaman içinde hızla değişmektedir. Böylece üstünlükler kalıcı değil, esnek bir içerik kazanmaktadır. Teoride, yalnızca doğal kaynak, sermaye veya işgücü avantajları tek tek değil, rekabet avantajı yaratan tüm faktörler birlikte dikkate alınmaktadır (Timurçin, 2010: 59). 
1995 yılı ve sonrasında ise, temelleri Marshall'a kadar uzanan verimlilik yaklaşımının, rekabet gücünü açıklayan en son yaklaşım olduğu kabul edilmek ile birlikte, günümüze kadar olan sürede, ileri teknolojiyle beraber gelişen küresel ekonomiye geçişin hızlanması, sektör sınırlarının neredeyse belirsizleşmesi, müşteri memnuniyetinin ön plana çıkması, endüstri toplumundan bilgi toplumuna geçiş aşamalarının yaşanması, yeni ve farklı ürünlerin pazara sürülme süresinin kısalması, rekabetin artması ve eski yönetim anlayışlarının sorgulanması, 1980'li yıllardan kalma rekabet anlayışıyla rekabet gücü elde etmenin mümkün olmadığını göstermektedir. Bugün bütün ekonomiler için geçerli olan, kalite, yenilik, esneklik, hız, farklılık, verimlilik ve mükemmeliyet rekabet gücünün yeni belirleyenleri olmuştur (Bahar ve Kozak, 2012: 22).

Genellikle rekabet ile ilgili literatür incelendiğinde çalışmalar imalat sektöründeki firmaların rekabetine dayanmaktadır ve turizm sektörünü kapsayan çalışmaların sınırlı olduğu görülmektedir. Turizm sektöründe rekabet incelendiğinde hiç kuşkusuz en önemli konu farklı deneyim ve çeşitli hizmetleri sunan destinasyonlar arasında rekabettir (Gürsoy vd., 2008: 2). Bu alanda en önemli çalışmalardan biride hiç kuşkusuz rekabetin genel çerçevesini oluşturup, turizm sektöründe rekabet seviyesini endüstri, ürün ve işletme bazında açıklayan Courch ve Ritchie ait olandır. Bu çalışmaya göre; bir turizm bölgesinin vatandaşlarına refah bir yaşam sağlayan olanaklar aynı zamanda o yerin rekabet gücünü de oluşturmaktadır (Courch ve Ritchie, 1999).

Kim (2000), turizm sektöründe rekabet ve rekabet gücünü açıklamaya yönelik olarak rekabet modeli geliştirmiştir. Bu modelde, turizm sektöründe rekabeti oluşturan kaynaklar dört açıdan incelenmektedir. Bunlar bir ülkenin doğal kaynaklarından başlayıp, turizm politikası, planlaması ve turizm talebine kadar birçok değişkeni içine almaktadır. Kim aynı zamanda Dwyer ile birlikte önceki çalışmalarına dayanarak bütünleştirilmiş rekabetçi modeli geliştirmişlerdir. Bu model rekabet gücüne etki eden faktörlerin neler oluğunu ortaya koymaktadır. Örneğin doğal kaynaklar (iklim, doğal güzellikler, tarihi ve kültürel değerleri) ve geliştirilmiş kaynaklar (turizm alt yapısı; konaklama tesisleri ulaşım sistemi vb.) ile birlikte destek faktör ve kaynaklar( hizmet kalitesi, konukseverlik ve pazar ilişkileri) rekabet gücü elde edilmesini sağlayan en temel unsurları içermektedir (Dwyer ve Kim, 2003: 400-405).

Prideaux (2000), destinasyon rekabetini diğer çalışmalardan farklı olarak, ulaşımın turizm rekabeti açısından önemi üzerinde durur. Çalışmasında belirlediği turizm akışını etkileyen faktörlerin (hükümet sorumluluğu, özel sektör faktörleri, ekonomik ve politik faktörler gibi) turist gönderen ve kabul eden ülkeler açısından incelenmesi gerektiğini vurgular.

Turizm bölgeleri konusunda yapılan ilk uygulamalı çalışmalardan biriside, Kozak ve Rimmington (1999) tarafından Türkiye'nin rekabet düzeyini ölçen çalışma olmuştur. Bu çalışma 1998 yılı yaz sezonunda Türkiye'yi ziyaret eden 294 İngiliz turist üzerine yapılmış, turistlere 1995-1998 yılları arasında ziyaret ettikleri bir ülke ile Türkiye'nin karşılaştırılması istenmiştir. Çalışmaya göre, katılımcıların Türkiye'de 
dâhil olmak üzere, Akdeniz ülkelerini genelde 3S için seçtiklerini göstermiştir. Buna ek olarak, konukseverlik ile fiyat düzeyi Türkiye açısından olumlu özellikler olarak ortaya çıkmıştır (Bahar ve Kozak, 2012: 103).

Bahar (2004) çalışmasında, Türkiye'nin turizm sektörü açısından Akdeniz Bölgesi içindeki karşılaştırmalı rekabet gücünü belirlemeye çalışmıştır. Bu amaçla, Türkiye geneli için Muğla ili örnek seçilmiş ve toplam 881 yabancı turist ile konaklama işletmeleri, seyahat acenteleri ve tur rehberlerinden oluşan 429 sektör temsilci ile anket yapılmıştır. Çalışma sonucunda Türkiye'nin Akdeniz Bölgesi içindeki en yakın rakiplerinin İspanya, Yunanistan, İtalya, Fransa ve Kıbrıs olduğu tespit edilmiştir. Ayrıca Türkiye'nin turizm sektöründe uluslararası rekabet gücünü etkileyen en önemli faktörün konukseverlik olduğu belirtilmiştir.

Alaeddinoğlu ve Samırkaş (2014) çalışmalarında, Kozak ve Rimmington (1999) tarafından Türkiye'nin rekabet düzeyini ölçen çalışma ile Bahar'ın (2004) Türkiye'nin turizm sektörü açısından Akdeniz Bölgesi içindeki karşılaştırmalı rekabet gücünü ölçen çalışmayı örnek alınarak, önemli bir turizm potansiyeline sahip olan Van ilinin turizmde rekabet gücünü ölçmek için bir alan araştırması yapmışlardır. Bu bağlamda Van kent merkezinde 57 işletmede 104 kişiye anket uygulanmıştır. Üç bölümden oluşan anket soruları işletme sahipleri ve yönetici pozisyonunda bulunan kişilerle yapılmıştır. Anket sonucunda ortaya çıkan bulguların en önemlileri, önceden seçilmiş illere göre rekabet düzeyleri konusunda, işletmelerin hem kendilerine hem de Van ilinin turizm kaynaklarına çok güveniyor olmaları ve var olan kaynakların her şekilde onları destekler nitelikte olduğunu düşünmeleridir.

\section{TRB2 BÖLGESININ SOSYO-EKONOMIK GÖSTERGELER VE TURIZM ARZ KAYNAKLARI AÇISINDAN DEĞERLENDİRILMESİ}

Bitlis, Hakkâri, Muş ve Van illerini kapsayan TRB2 Bölgesi, 41.558 kilometrekare yüzölçümü ile Türkiye toplam yüzölçümünün \%5'ini kapsayan ve 2.022.373 nüfusu ile Türkiye toplam nüfusunun \%2,75'ini barındıran bir bölgedir. Bölge, kuzeyde Erzurum ve Muş, kuzeydoğuda Ağrı, batıda Bingöl, güneybatıda Diyarbakır, Batman Siirt, Şırnak güneyde, Irak doğuda İran ile komşudur (DAKA, 2013: 12).

TRB2 Bölgesi, sosyal ve ekonomik veriler açısından ülke ortalamasına kıyasla oldukça geri kalmış olup genellikle son sıralarda yer almaktadır. Türkiye'nin il ve bölgelerinin sosyo-ekonomik gelişmişlik seviyesine ilişkin olarak 2003 yılında Devlet Planlama Teşkilatı Müsteşarlığı'nca yapılan “ïllerin ve Bölgelerin Sosyo-Ekonomik Gelişmişlik Sıralaması Araştırması", 2002/4720 sayılı Bakanlar Kurulu Kararı ile tanımlanan düzey 2 bölgelerini de incelemeye alınmış olup TRB2 Bölgesi söz konusu sıralamada 26 düzey 2 bölgesi içerisinde son sırada yer almıştır (DAKA, 2014: 13). Aynı şekilde TÜİK tarafından 2011 yılında hazırlanan il ve bölgesel bazda hazırlanan kişi başına gayri safi katma değer rakamlarına göre TRB2 bölgesi 3.515 dolar ile 26 bölge içinde son sıradadır (tuik.gov.tr). Ayrıca Bölge'de orta büyüklükte sayılabilecek nitelikte bir kaç firma haricinde tüm işletmeler mikro ölçeklidir. Mevcut orta 
büyüklükteki işletmeler et ürünleri işleme, süt işleme, yapı malzemeleri üretimi, geri dönüşüm, tekstil gibi sektörlerde faaliyet göstermektedir (DAKA, 2011).

TRB2 Bölgesi ile ilgi önemli bir nokta, tarım sektörünün gayri safi katma değerden (GSKD) aldığı paydır. 2008 verilerine göre bu pay \%21,3 olup Türkiye ortalamasının $(\% 8,5)$ yaklaşık 2,5 katıdır. Tarımda ilkel yöntemlerin kullanılmasına ve geçimlik ekonominin çok yaygın olmasına rağmen tarım sektörünün GSKD'den bu kadar yüksek pay almasının sebebi başta sanayi olmak üzere diğer sektörlerin gelişmemiş olmasıdır. Endüstrileşememiş, katma değer yaratamayan, yeni yatırımları finanse edecek sermaye birikimini sağlayamayan ve verimsiz yöntemler dolayısıyla ihtiyaç duyulandan çok daha fazla kaynağı (toprak, sermaye, emek, girişimcilik) tüketen tarım sektörü Bölge'nin geri kalmışlı̆̆ının temel sebebi olarak görülmektedir (DAKA,2014:9). Bu durum bölgede istihdam rakamlarına da yansımaktadır. Sanayinin ve hizmetler sektörünün gelişmemiş olması, işgücüne katılım ve istihdam oranlarının düşük olmasının sebeplerinden birini oluşturmaktadır.

Bölgede istihdam verileri açısından değerlendirildiğinde, işgücüne katılım ve istihdam oranlarının Türkiye ortalamasından düşük olduğu görülmektedir. Bölge içerisinde işgücüne katılım oranının en fazla olduğu il \%46.5 ile Bitlis, en düşük olduğu il ise \%45.2 ile Hakkâri iken Van'da bu oran Bitlis'e paralel olarak \%46.2 ile ülke ortalamasının altındadır. İşsizlik oranına bakıldığında ise, bütün iller Türkiye ortalamasinın üstündedir.

Tablo 1. TRB2 Bölgesi İllerinde İşgücüne Katılma, İşsizlik ve İstihdam Verileri (2013)*

\begin{tabular}{|l|c|c|c|}
\hline & $\begin{array}{c}\text { İşgücüne Katılma } \\
\text { Oranı (\%) }\end{array}$ & İşsizlik Oranı (\%) & İstihdam Oranı (\%) \\
\hline Bitlis & 46.5 & 10.6 & 41.5 \\
\hline Hakkâri & 45.2 & 11.7 & 39.9 \\
\hline Muş & 46 & 10.4 & 41.2 \\
\hline Van & 46.2 & 10.3 & 41.4 \\
\hline TÜRKİYE & 50.8 & 12 & 45.9 \\
\hline
\end{tabular}

Kaynak: Tuik.gov.tr'den yararlanılarak yazarlar tarafından düzenlenmiştir. (Erişim Tarihi: 05.09.2017)

*TÜİK'in yayınlandığı il bazında işgücü verileri en son 2013 tarihini içermektedir.

TRB2 bölgesi, iktisadi hoşnutsuzluk göstergeleri olarak, enflasyon ve işsizlik oranları ile sosyal hoşnutsuzluk göstergeleri olarak net göç hızı, kaba boşanma oranı, kaba intihar oranı, suç oranları ve genel seçimlere katılım oranı gibi verileri dikkate alınarak oluşturulan "bölgesel hoşnutsuzluk endeksine", göre de değerlendirildiğinde, 2007-2010 döneminde Türkiye' de hoşnutsuzluk düzeyi en yüksek TRC3'ten (Batman, Mardin, Siirt ve Şırnak) sonra ikinci bölge olmuştur (Samırkaş, 2013: 103).

TRB2 Bölgesi'ni turizm arz kaynakları açısından değerlendirdiğimizde, sahip olduğu 842 tescilli kültür varlığı ve birçok arkeolojik ve doğal sit alanları, endemik bitki ve hayvan türleri, göl ve akarsuları, dağ ve yaylaları ile turizm kapasitesi yüksek bir merkezdir. Bu kapasite içinde, Van Gölü'nün Türkiye'nin en büyük gölü ve Nemrut 
Gölü'nün en büyük krater gölü olmasının önemli bir payı vardır (DAKA, 2014: 13). Özellikle Van, Urartu Medeniyetinin başkenti olma ve bu medeniyetin onlarca tarihi yapısına ev sahipliği yapma, bir taraftan da Türkiye'nin en büyük gölü olan Van Gölünün bölgede yer alması ile başta su sporları olmak üzere, dört mevsim turizm yapılabilme özelliğine sahip bir bölgedir. Ayrıca bölgede kültürel miras varlıkları ölçek ve çeşit açısından oldukça fazladır, ancak bunlardan yerel halkın ve turistlerin ortak yararına sürdürülebilir bir şekilde faydalanmak adına çok az şey yapılmıştır. Aşağıdaki Tablo 2'de TRB2 bölgesinde yer alan kültürel miras varlıkları verilmiştir.

Tablo 2. TRB2 Bölgesi Kültür Varlıkları

\begin{tabular}{|l|c|c|c|c|c|}
\hline & Bitlis & Hakkâri & Muş & Van & Toplam \\
\hline Camiler & 37 & 6 & 5 & 22 & 70 \\
\hline Türbeler & 26 & 2 & 6 & 11 & 45 \\
\hline Kaleler & 9 & 4 & 15 & 24 & 52 \\
\hline Saraylar & 0 & 2 & & & 2 \\
\hline Kiliseler & 24 & 15 & 6 & 30 & 75 \\
\hline Mezarlıklar & 22 & & 4 & 29 & 55 \\
\hline Hamamlar & 9 & & 16 & 1 & 26 \\
\hline Hanlar & 7 & & 1 & 2 & 10 \\
\hline Çeşmeler & 24 & & 2 & 4 & 30 \\
\hline Köprüler & 23 & 1 & & 11 & 35 \\
\hline Medreseler & 7 & 3 & 1 & 6 & 17 \\
\hline Şehit Anıtları & & & 5 & 1 & 6 \\
\hline Şehir Kapıları & 1 & & & 3 & 4 \\
\hline Kaplıcalar & & & & & \\
\hline Höyükler & & & 16 & 3 & 19 \\
\hline Şelaleler & & & & & \\
\hline Konaklar-Kamusal & & & 1 & 2 & 3 \\
\hline Konaklar-Özel & 420 & 2 & 1 & 1 & 424 \\
\hline Toplam & $\mathbf{6 0 9}$ & $\mathbf{3 5}$ & $\mathbf{7 9}$ & $\mathbf{1 5 0}$ & $\mathbf{8 7 3}$ \\
\hline
\end{tabular}

Kaynak: İl Turizm Müdürlüğü ve DAKA, ( 2013), s.334

Turizmin bölge içindeki yerini ve rekabet gücünü belirleyebilmek için, bölgedeki tesis ve yatak sayısı, bölgeye gelen yerli ve yabancı turistlerin kalış süreleri ve doluluk oranlarını incelemek gerekmektedir. Bu bağlamda Tablo 3'de bakanlık ve belediye belgeli tesis oda ve yatak sayısı karşılaştırmalı bir şekilde verilmiştir. Tablo 3 incelendiğinde, tesis sayısı ve kapasitesi açısından en iyi durumda olan il 32 tesis ile Van'dır. Ayrıca bölge içinde tek 5 yıldızlı otele sahip olan Van ilidir. Ayrıca, Van'da 2 tane 5 yıldızlı, 3 tane 4 yıldızlı, 2 tane 3 yıldızlı ve 4 tane 2 yıldızlı otel mevcuttur. TRB2 bölgesinde turizm göstergeleri açısından en dezavantajlı il ise Hakkâri'dir. Hakkâri'de sadece bakanlık ve belediye belgeli 9 tesis bulunmaktadır. TRB2 bölgesinde toplam tesis sayısına baktığımızda 69 tesis mevcuttur. Türkiye'de üç yüz binin üzerinde tesis olduğu düşünüldüğünde bu tesislerin sadece 69'u yani yaklaşık olarak on binde ikisi TRB2 bölgesinde yer almaktadır. 
Tablo 3. Bakanlık ve Belediye Belgeli Tesis Sayısı ve Kapasiteleri

\begin{tabular}{|c|c|c|c|c|c|c|}
\hline \multirow{2}{*}{$\begin{array}{l}\text { İSTATİSTIKİ } \\
\text { BÖLGE } \\
\text { BİRIMLERİ } \\
\text { SINIFLAMASI }\end{array}$} & \multicolumn{3}{|c|}{$\begin{array}{c}\text { Bakanlık İşletme Belgeli Tesis } \\
\text { Sayısı ve Kapasiteleri }\end{array}$} & \multicolumn{3}{|c|}{$\begin{array}{l}\text { Belediye İşletme Belgeli Tesis } \\
\text { Sayısı ve Kapasiteleri }\end{array}$} \\
\hline & $\begin{array}{l}\text { TESIS } \\
\text { SAYISI }\end{array}$ & $\begin{array}{l}\text { ODA } \\
\text { SAYISI }\end{array}$ & $\begin{array}{l}\text { YATAK } \\
\text { SAYISI }\end{array}$ & $\begin{array}{l}\text { TESIS } \\
\text { SAYISI }\end{array}$ & $\begin{array}{c}\text { ODA } \\
\text { SAYISI }\end{array}$ & $\begin{array}{l}\text { YATAK } \\
\text { SAYISI }\end{array}$ \\
\hline VAN & 10 & 541 & 1.226 & 22 & 803 & 1.559 \\
\hline MUŞ & 6 & 185 & 398 & 6 & 127 & 267 \\
\hline BİTLİS & 3 & 164 & 334 & 13 & 336 & 670 \\
\hline HAKKÂRI & 4 & 126 & 255 & 5 & 103 & 207 \\
\hline TRB2 Toplam & 23 & 1.016 & 2.213 & 46 & 1.369 & 2.703 \\
\hline
\end{tabular}

Kaynak: www.turizm.gov.tr; daka.org.tr, TRB2 Bölgesi, 2011- 2013 Bölge Planı (Erişim Tarihi:05.09.2017)

Tablo 4. Turizm İşletme Belgeli ve Belediye Belgeli Konaklama Tesislerinde Geliş ve Geceleme Sayıları (2016)

\begin{tabular}{|l|c|c|c|c|}
\hline \multirow{2}{*}{ BÖLGE VE TÜRKIYYE } & \multicolumn{2}{|c|}{$\begin{array}{c}\text { Turizm İşl. Bel. Konaklama } \\
\text { Tesislerinde Geliş ve } \\
\text { Geceleme Sayıları }\end{array}$} & \multicolumn{2}{c|}{$\begin{array}{c}\text { Belediye Bel. Konaklama } \\
\text { Tesislerinde Geliş ve } \\
\text { Geceleme Sayırı }\end{array}$} \\
\cline { 2 - 5 } & Yerli & Yabanc1 & Yerli & Yabanc1 \\
\hline TRB2 Toplam & 187.617 & 34.449 & 86.411 & 1.798 \\
\hline TÜRKIYYE & 22.676 .261 & 14.269 .381 & 18.659 .732 & 3.778 .493 \\
\hline
\end{tabular}

Kaynak: www.tuik.gov.tr (Erişim Tarihi: 04.09.2017)

Tablo 5. Konaklama Tesislerinde Doluluk Oranları (\%)

\begin{tabular}{|l|l|l|l|l|}
\hline Belge Türü & \multicolumn{1}{|c|}{ Bitlis } & \multicolumn{1}{|c|}{ Hakkâri } & \multicolumn{1}{c|}{ Muş } & Van \\
\hline Bakanlık İșletme Belgeli & 20.1 & 61.4 & 35.5 & 34.1 \\
\hline Belediye İşletme Belgeli & 25.5 & 22.3 & 28.4 & 44.1 \\
\hline
\end{tabular}

Kaynak: daka.org.tr, TRB2 Bölgesi, 2011- 2013 Bölge Planı (Erişim Tarihi: 04.09.2017)

Tablo 4'te 2016 yılında bölgeye geliş ve geceleme süreleri verilmiştir. Buna göre turizm işletme belgeli ve belediye belgeli tesislerde yabancı turist açısından geceleme süresi 36.238 gibi çok düşük bir rakam iken bu oran Türkiye'de 18.047.874'tür. Bu durum yerli turist açısından da geçerlidir. Bölge turizm arz kaynakları açısından önemli bir potansiyele sahip olmasına rağmen yeterince turist çekememektedir. Tablo 5 'te ise konaklama tesislerinde ki doluluk oranları verilmiştir. Türkiye'de turizm hareketlerindeki değişimlere bağlı olarak doluluk oranları dalgalı bir seyir izlese de ortalama olarak doluluk oranlarının \%48-49 civarında olduğu söylenebilir (tursab.org.tr). Bölgede, bakanlık işletme belgeli ve belediye belgeli konaklama işletmelerinin doluluk oranları incelendiğinde ve Türkiye ile karşılaştırıldığında kapasitelerinin çok altında çalıştıkları görülmektedir. Yukarıdaki tablolar birlikte değerlendirildiğinde maalesef TRB2 bölgesinin sosyo-ekonomik anlamda görülen az gelişmişliği turizm göstergeleri açısından da kendini göstermektedir. 


\section{YÖNTEM}

TRB2 bölgesi olarak adlandırılan Bitlis, Hakkâri, Muş ve Van'ın turizmde rekabet edebilirlik düzeylerini, seçilmiş illere göre ölçmeyi amaçlayan çalışma, hem gözlem hem de anketle gerçekleştirilmiş bir saha çalışmasından oluşmaktadır. Uzun yıllardır söz konusu illerle ilgili birçok turizm çalışması yapmış olan ve TRB2 illerinin turizme ilişkin verilerini takip eden yazarlar, rekabet düzeyini sağlıklı ölçmek için ayrıca hizmet veren turizm işletmelerinin görüşlerine de başvurulmuştur. Bu bağlamda Bitlis (64), Hakkâri (60), Muş (65) ve Van'da (71) toplam 260 anket gerçekleştirilmiştir. Her ne kadar turist sayısı, turizme konu olan kaynaklar, tesisleşme ve diğer değişkenler konusunda iller arasında bir farklılaşma olsa da anket sayılarında ola bildiğince eşit dağılıma önem gösterilmiştir. Temel veri katılımcılarla yüz yüze yapılan görüşmeler sonucunda gerçekleştirilen 2 sayfalık araştırma sorularından elde edilmiştir. Araştırma sorularını doldurmaya 252 sektör çalışanı olumlu yanıt vermiştir. Söz konusu anket çalışması, 2014 Nisan-Mayıs ayları arasında bölgede yer alan Bitlis, Muş, Hakkâri ve Van il merkezlerinde gerçekleştirilmiştir. Anket çalışması 13 adet çoktan seçmeli ve açık uçlu sorunun yanında 32 adet 5'li Likert yöntemine göre hazırlanmış sorulardan oluşmaktadır. Araştırmanın sağlıklı bir şekilde gerçekleşmesi için katılımcıların seçimine özen gösterilmiş ve farklı turizm işletmeleri arasından deneklerin görüşü alınmıştır.

Dizin taraması ve uzman görüşlerinin alınması neticesinde hazırlanan anket soruları 4 kategoriye ayrılmıştır. İlk kategoride katılımcıların kişisel bilgileri ve işletmenin yapısına ilişkin sorular sorulurken, ikinci kısımda, seçilmiş illerin ve kıyaslama yapılan illerin belirlenmesi yer almaktadır. Üçüncü bölümde rekabet düzeyini yerel dinamikler açısından ölçülmesi amaçlanırken, dördüncü bölümde, ulusal düzeyde gerçekleşecek tehdit ve risklere karşı rekabet düzeyinin ölçülmesi amaçlanmıştır. Anketlerin önemli bir kısmı deneklerle yüz yüze gerçekleştirilirken çok az bir kısmı ise ki, özelliklede işletme sahipleri anketleri bir sonraki gün vermek suretiyle doldurmayı kabul etmişlerdir. Zira bu tarz anketlerde bazı sorulara deneklerin cevap vermedikleri anlaşılmaktadır. Elde edilen bütün anketler SPSS 18 programında değerlendirilmiş ve elde edilen araştırma bulguları metin içerisinde verilmiştir.

\section{ARAŞTIRMA BULGULARI VE TARTIŞMA}

Bitlis, Hakkâri, Muş ve Van'ın seçilmiş illere göre rekabet düzeylerini ölçmeyi amaçlayan bu çalışma, aynı zamanda yerel yönetimlerin gerçekleştirilen turizm faaliyetlerine dâhil olup olmadıkları, sürece dâhil olan yerel yönetimlerin sürecin neresinde oldukları gibi birçok değişkenin de incelendiği bir araştırma niteliği taşımaktadır. Birincil kaynaklara dayalı olarak gerçekleştirilen araştırma ampirik bir çalışmadır. TRB2 Bölgesiyle rekabet edebilirlik konusunda seçilen iller sırasıyla, Trabzon, Mardin, Şanlıurfa, Gaziantep, Adıyaman, Diyarbakır, Kayseri, Nevşehir, Ağrı ve Erzurum şeklindedir. 
Tablo 6. Daha Önce Seçilen İllerde Bulunma ve Ziyaret Etme

\begin{tabular}{|c|c|c|c|c|c|c|c|c|}
\hline \multirow[b]{2}{*}{ Seçilen İller } & \multicolumn{2}{|c|}{ Bitlis } & \multicolumn{2}{|c|}{ Hakkâri } & \multicolumn{2}{|c|}{ Muş } & \multicolumn{2}{|c|}{ Van } \\
\hline & $F$ & $\%$ & $\mathbf{F}$ & $\%$ & $F$ & $\%$ & $\mathbf{F}$ & $\%$ \\
\hline Trabzon & 9 & 14,1 & 8 & 13,3 & 7 & 10,7 & 15 & 21,2 \\
\hline Mardin & 6 & 9,4 & 9 & 15 & 8 & 12,3 & 8 & 11,3 \\
\hline Şanliurfa & 7 & 11 & 2 & 3,3 & 6 & 9,2 & 7 & 9,9 \\
\hline Gaziantep & 7 & 11 & 4 & 6,7 & 8 & 12,3 & 7 & 9,9 \\
\hline Adiyaman & 2 & 3,1 & 4 & 6,7 & 4 & 6,2 & 2 & 2,8 \\
\hline Diyarbakır & 22 & 34,4 & 20 & 33,3 & 12 & 18,6 & 17 & 23,9 \\
\hline Kayseri & 5 & 7,8 & 3 & 5 & 3 & 4,6 & 3 & 4,2 \\
\hline Nevşehir & 2 & 3,1 & 2 & 3,3 & 2 & 3,1 & 3 & 4,2 \\
\hline Ağrı & 1 & 1,6 & 6 & 10 & 8 & 12,3 & 3 & 4,2 \\
\hline Erzurum & 3 & 4,7 & 2 & 3,3 & 7 & 10,8 & 6 & 8,4 \\
\hline Toplam & 64 & 100 & 60 & 100 & 65 & 100 & 71 & 100 \\
\hline
\end{tabular}

TRB2 Bölgesini oluşturan iller ile yukarıda isimleri verilen illerin karşılaştırılmasının iki temel nedeni vardır. Bunlardan ilki, gerek TRB2 Bölgesi illerinin ve gerekse söz konusu diğer illerin turizm geçmişleri ve büyük oranda turizme bakışlarının benzer olması, bir diğeri ise, benzer turizm çeşitlerini pazarlıyor olmaları ve Türkiye'de kitle turizm bölgeleri bir tarafa bırakılırsa ülkemizi deneyimleyen turistlerin profillerinin büyük oranda benzerlik göstermesidir. Dolayısıyla TRB2 bölgesinde turizm alanında hizmet veren işletmelerin kendilerini Antalya, İstanbul ve Muğla gibi milyonlarca turiste hizmet veren büyük turizm bölgeleri ile kıyaslamaları anlamlı değildir. Bu nedenle Kayseri, Nevşehir, Trabzon, Erzurum, Gaziantep ve Diyarbakır gibi nispeten iyi, Mardin, Şanlıurfa, Ağrı ve Adıyaman gibi orta düzeyde kentlerle kıyaslanması daha anlamlıdır.

Bu bağlamda öncelikle seçilen iller ile TRB2 Bölgesindeki iller arasında ziyaret etme ve sıklık durumu ele alınmıştır. Deneklere seçilen illerden hangilerine ve ne sıklıkta gittikleri sorulmuş ve bu sonuçlar üzerinden rekabet düzeyi ele alınmıştır. Dolayısıyla verilen cevaplar ziyaret edilen iller üzerinden gerçekleşmiş ve rekabete ilişkin sonuçlar bu tablo üzerinden yorumlanmıştır. Tablo 6'dan da anlaşılacağı üzere araştırmaya konu olan illerdeki (Bitlis, Hakkari, Muş ve Van) deneklerin ağırlıklı olarak ziyaret ettikleri il Diyarbakır olmuştur. Diyarbakır'ı, Trabzon, Urfa ve Mardin takip etmiştir. Ziyaret edilen il kadar önemli diğer bir değişken ise o ilin kaç kez ziyaret edildiği (kaç kez) bilgisidir. Bu soruda da Diyarbakır en sık ziyaret edilen il olarak ortaya çıkmaktadır. Diyarbakır'ı Mardin, Urfa, Trabzon ve Erzurum takip etmektedir.

\subsection{Eğitim ve Sayısal Bilgiler}

Araştırma temelde iki farklı eksende ele alınmıştır. Bunlardan ilki, TRB2 Bölgesindeki illerden ankete katılan işletme ve çalışanların eğitim ve sayısal bilgilerine ilişkin, ikincisi ise TRB2 illerinin rekabet düzeyini ölçmeye yöneliktir. Birinci grupta yer alan sorulardan ilki ankete katılan deneklerin işletmedeki görevlerine ilişkindir. Görev dağılımlarına bakıldığında Van'dan ankete katılan deneklerin \%28,6'sının işletmenin sahibi olduğu anlaşılırken bu oran Muşta \%36,9 ve Bitlis'te 40.6 şeklinde 
gerçekleşmiştir. Tablo 7'de de görüldügü gibi ankete katılanların önemli bir kısmı ya işletme sahibi ya da diğer grupta ifade edilen kişilerden oluşmaktadır. Diğer kategorisindeki deneklerin seçilmesinde özellikle küçük işletmelerde karşılaşılan aile işletmeciliğinin rolü belirleyici olmuştur. Çünkü işletmenin sahibi aynı zamanda müdürü pozisyonunda da olabilmektedir. Bu nedenle çeşitlilik arz etmesi adına yönetici ve karar alma süreçlerinde etkili olan kişilere anket uygulanmıştır. Bu arada illerde bulunan ulusal turizm şirketleri (başta konaklama tesisleri) özellikle ankete dahil edilmiştir.

Tablo 7. Ankete Katılan Deneklerin Görev Tanımı

\begin{tabular}{|l|c|c|c|c|c|c|c|c|}
\hline & \multicolumn{2}{|c|}{ Bitlis } & \multicolumn{2}{c|}{ Hakkâri } & \multicolumn{2}{c|}{ Muş } & \multicolumn{2}{c|}{ Van } \\
\hline Göreviniz & F & $\mathbf{\%}$ & F & \multicolumn{1}{c|}{ F } & F & \% & F & \% \\
\hline İşletme Sahibi & 26 & 40.6 & 22 & 36,7 & 24 & 36,9 & 20 & 28,6 \\
\hline Ortak & 8 & 12,5 & 5 & 8,3 & 2 & 3,1 & 7 & 9,9 \\
\hline Müdür & 5 & 7,8 & 6 & 10 & 18 & 27,7 & 12 & 16,9 \\
\hline Departman Müdürü & 4 & 6,3 & 4 & 6,7 & 4 & 6,2 & 8 & 11,3 \\
\hline Diğer & 21 & 32,9 & 23 & 38,4 & 17 & 26,2 & 24 & 33,8 \\
\hline Toplam & $\mathbf{6 4}$ & $\mathbf{1 0 0}$ & $\mathbf{6 0}$ & $\mathbf{1 0 0}$ & $\mathbf{6 5}$ & $\mathbf{1 0 0}$ & $\mathbf{7 1}$ & $\mathbf{1 0 0}$ \\
\hline
\end{tabular}

Ankete katılanların görevleri kadar önemli bir diğer değişken eğitim düzeyleridir. Zira turizme hizmet eden bir işletmenin yöneticilerinin ve çalışanlarının ne oranda eğitimli oldukları ve daha önemlisi akademik düzeyde turizm eğitimi alıp almadıkları bilgisi işletmenin başarısında belirleyicidir. Bu anlamda deneklerin eğitim durumları incelendiğinde, Van'dan ankete katılan deneklerin bir okul bitirme durumu ve turizmle ilgili bir fakülte ve ön lisanstan mezun olma durumunun düşük olduğu görülmektedir. Toplam 71 deneğin \%53.4'ünün bir fakülteden mezun olduğu bunların içinden \% 21,1'inin ise turizmle ilişkili bir programdan mezun olduğu anlaşılmaktadır. Buna karşın durum diğer illerde biraz daha düşündürücüdür. Bitlis, Hakkâri ve Muş'ta deneklerin \% 60'tan fazlası ilk, orta ve lise muzunudur. Herhangi bir turizm programından mezun olma durumu ise Bitlis'te \% 7.9, Hakkari'de \% 1.7 ve Muş'ta $\% 13.9$ 'dur.

Araştırmaya konu olan turizm işletmelerin türü rekabet düzeyi çalışmasında bir diğer istatistikî bilgi olarak sorulara eklenmiştir. Bu anlamda dört ilde de konaklama tesisleri birinci derecede anket yapılan işletmeler olarak öne çıkmıştır. Örneğin bu oran Van'da \%33.2 olurken, Muşta \%57.1, Hakkari'de 30.8, Bitlis'te 37.5 şeklinde gerçekleşmiştir. İkinci sırada restoran-kafe, üçüncü sırada ise seyahat acenteleri sıralanmıştır. Konaklama tesislerinde anket uygulanan kişilerin hizmet verdikleri konaklama tesislerinin sımıfına ilişkin bilgiler incelendiğinde, Van'dan katılanların \% 20.4'ünün 5 yıldızlı otellerde, \% 25.9'unun 4 yıldızlı otellerde ve \%24.1'nin ise 3 yıldızlı otellerde çalıştıkları görülmektedir. Van hariç düğer illerde 5 yıldızlı otel olmadığı için diğer kentlerde ağırlıklı olarak 4 ve 3 yıldızlı oteller seçilmiştir. Anketin gerçekleştirildiği seyahat acentelerinin sınıflarına bakıldığında ise örneğin Muş'ta A sınıfı işletmelerde ankete katılanların oranı \% 32.5'lerde kalır iken Hakkari'de A sınıfı acente çalışanlarına uygulanan anket \% 60, Bitlis'te \%79.4 ve Van'da 68.4 şeklindedir. B ve $C$ sınıfı acentelere uygulanan anket sayısı nispeten düşük kalmıştır. 
TRB2 Bölgesindeki turizme hizmet veren işletmelerde çalışanların sayıları incelendiğinde ağırlıklı olarak 1-10 kişi çalıştıran işletmelerin görüldüğü anlaşılmaktadır. Van'daki işletmelerin \%39.4'ü 1-10 kişi çalıştırırken, \% 21.1'i 11-20 ve \% 29.6'sı 51 ve üzeri şeklinde işçi çalıştırdığ1 anlaşılmaktadır. 21-30, 31-40 ve 41-50 aralığında işçi çalıştıran işletme oransal olarak düşük kalmaktadır. Yukarıda da görüldügü üzere Van'da ağırlıklı olarak 3 kategoride işçi sayısı bulunmaktadır. Ancak çalıştırılan işçi sayısı bakımından diğer üç il Van'dan daha farklı bir tablo sergilemektedir. Şöyle ki Van'da nispeten daha geniş bir yelpazede işçi çalıştıran işletmeler olsa da diğer üç ilde 1-10 arası işçi çalıştıran işletmelerin oranı toplam içindeki payı Bitlis \%76.6, Hakkari \% 82.6 ve Muş \% 66.2 şeklindedir. 51+ işçi çalıştıran işletme oranı ise Bitlis \% 6.3, Hakkari \% 0 ve Muş'ta \% 16.9 şeklindedir. Turizm işletmelerinde çalışan kişi sayısı kadar önemli bir diğer değişken çalışanların turizm mezunu olma durumudur. Bu çerçeveden bakıldığında ağırlıklı olarak 1-5 kişinin çalıştırıldığı anlaşılmaktadır. 1-5 kişi turizm mezunu çalıştıran işletme sayısı Van'da \% 41.7 iken, Bitlis'te 51.6, Hakkari'de \% 57.3 ve Muş'ta \% 46.3 şeklindedir. 20 ve daha üzeri turizm mezunu çalıştıran işletme sayısı ise Van'da \% 24.1 iken, Bitlis'te 4.7, Hakkari'de \% 0 ve Muş'ta \% 9.2 olarak tespit edilmiştir.

Araştırmaya konu olan illerdeki işletmelerin turizmde hizmet verme ve kişilerin turizm sektöründe çalışma sürelerine ilişkin bilgiler incelendiğinde bu anlamda Van'ın oldukça eski bir turizm geçmişine sahip olduğu anlaşılmaktadır. Hizmet süreleri 1-3, 4-6, 7-9, ve $10+$ şeklinde kategorize edilmiştir. Van'daki işletmelerin \%74.5'i 10 ve üzeri yılı seçerken diğer illerde daha dengeli bir dağılımın olduğu anlaşılmaktadır. Örneğin, Bitlis'te 1-3 yıl hizmet veren işletme sayısı \% 11.4, 4-6 yılı seçenler \% 14.3, 7-9 yılı seçenler \% 34.6 ve 10 ve üzerini seçenler ise \% 39.7'dir. Şüphesiz işletmelerin turizme hizmet verme süreleri kadar kişilerinde turizm geçmişi önemlidir. Bu anlamda yöneltilen soruya üç ilden katılan denekler dengeli bir dağılım göstermiş ise de ağırlıklı seçenek 7-9 ve $10+$ şeklindedir. Bir önceki soruda olduğu gibi bu soruda da Van'ın ayrıştığını görmekteyiz. Şöyle ki, Van'dan katılanların dağılımında 10 ve üzeri yılı seçenlerin oranı \% 58.6 ile ön plana çıkmaktadır. Bu sonuç hem Van'ın turizm geçmişine işaret etmekte hem de turizm sektöründe çalışanların aynı zamanda bir turizm geçmişine de sahip oldukları sonucunu çıkarmaktadır. Yukarıdaki iki değişken turist sayısı ile de doğrulanmaktadır. Zira hizmet verilen turist sayısına bakıldığında dört ilde de ağırlıklı şıkkın 0-50 turist aralığında olduğu anlaşılmaktadır. Ancak burada istisna olarak Van ön plana çıkmaktadır. Zira Van yabancı turist sayısında diğer üç ilden farklılaşmaktadır. Şöyle ki her ne kadar en önemli yüzdeyi 0-50 arası ( \%28.9) oluşturuyorsa da 300-500 turiste hizmet veren işletme sayısı \% 26.7'yle diğer illerden ayrışmaktadır.

\subsection{Seçilmiş İllere Göre Rekabet Düzeyi}

Turizmin artan önemi ülkelerin ve destinasyonların bu pastadan pay alma girişimlerini hızlandırmakta ve uluslararası rekabeti şiddetlendirmektedir. Rekabetçi bir pazarda faaliyet gösteren destinasyonlar için turizm planlaması, destinasyonun başarısındaki en önemli konulardan biridir (Costa, 2001; Lai, Li ve Feng, 2006; Sharpley, 2008). Dolayısıyla benzer ürünleri pazarlayan turizm bölgeleriyle rekabet 
edebilirlik seviyenizi ortaya koymadan turizme ilişkin alacağınız her türlü karar veya yapacağınız her uygulama mutlak surette eksiktir. Çünkü turizmde var olmak için ya farklı olmalısınız ya da rekabet düzeyinizin yüksek olması gerekmektedir. Ancak rekabet düzeyinin ölçülmesi oldukça zor ve farklı değişkenlerin bilinmesine bağlıdır. $\mathrm{Bu}$ değişkenlerden biri ve beklide en önemlisi sektörde çalışan ve işletme sahibi insanların konuya nasıl baktığı bilgisidir. Buradan hareketle TRB2 bölgesindeki illerde hizmet veren 260 adet turizm işletmesi çalışanına ve sahibine anket uygulanmıştır. Uygulanan anketlerde Van, Hakkari, Muş ve Bitlisin yukarıda söz konusu olan illerden sadece biriyle kıyaslamaları istenmiştir.

$\mathrm{Bu}$ bağlamda Van'dan ankete katılan 70 kişinin Van'ı kıyasladıkları iller, sırasıyla, \% 23,9 ile Diyarbakır, \% 21.1 ile Trabzon, \%12.7 ile Mardin, \% \%9,9 ile Erzurum, \% 7 ile Antep ve Kayseri olurken, diğer üç ilde Erzurum, Trabzon, Gaziantep ve Kayseri rekabet etmek için çokta tercih edilmedikleri anlaşılmaktadır. Bitlis ilinin birinci tercihi \%32,4 ile Diyarbakır, Muş'un birinci tercihi \%27,8 ile Mardin ve Hakkâri'nin \%23,6 Diyarbakır ve \%22,7 Mardin şeklinde olduğu anlaşılmaktadır. Bu durum büyük ölçüde yakınlık ve muhtemel rakip olarak görülen illere yönelik bir yaklaşımın sonucu olarak değerlendirilebilir. Ancak burada Van'ın daha geniş bir yelpazede farklı bölgelerin kentleriyle kıyaslama yapması büyük ölçüde, daha geniş bir konsepte turizm arzı yaratması, konumunun getirdiği avantaj, turizm çeşidindeki zenginlik ve turizm geçmişine sahip olması şeklinde özetlenebilir. TRB2 Bölgesindeki bütün illerin ağırlıklı olarak birçok kez ziyaret ettikleri il birinci sırada Diyarbakır gelirken, burada da Van'dan ankete katılan deneklerin Trabzon, Erzurum ve Kayseri'yi de Diyarbakır kadar deneyimlemeleri ve yakın tarihlerde bu kentlere ziyaretler gerçekleştirmeleri anlamlıdır.

Deneklere yöneltilen üçüncü soru hizmetin kalitesiyle ilgilidir. Van'dan ankete katlan denekler kıyasladıkları illere göre Van'ın hizmet kalitesini ilk iki sırayı \% 49,3 ile iyi ve \%18,3 ile çok iyi şeklinde ifade ederlerken, Bitlis'ten katılan deneklerin \% 51,6's1 kötü ve $\% 17,2$ 'si ise çok kötü şeklinde cevap vermişlerdir. Hakkari bu soruya \%43,3 ile çok kötü ve \% 36,7 ile kötü, Muş birinci sırada \% 50,8 ile kötü cevabını verirken ikinci sırada en yüksek oran \%21,5 ile iyi olmuştur. Dolayısıyla Van hariç diğer üç ilde de hizmet kalitesinin kötü olduğu anlaşılmaktadır. Ancak Muş'ta bazı denekler bu duruma karşı olduklarını ifade etmekteler ya da bir şekilde hizmet kalitelerinin iyi olduğunu düşünmektedirler. Söz konusu deneklerin kıyaslamayı yaptıkları illere bakıldığında kıyaslamanın Ağrı ve Mardin'le yapıldığı anlaşılmaktadır.

Turizmde en önemli arz kaynaklarından biri de turistik ürün (çekicilikler) çeşitliliğidir. Araştırmaya konu olan illerin bu soruya verdikleri cevap oldukça düşündürücüdür. Zira Van hariç diğer üç ildeki denekler mevcut turistik ürün çeşitlerine yeterince güvenmiyorlar. Şöyle ki, Hakkâri' den ankete katılan deneklerin \% 56,7'si, Bitlis'ten katılanların 46,9'u, Muş'tan katılanların ise \% 38,6'sı kötü şıkkını birinci sırada işaretlerlerken, Van'dan katılan denekler bu soruya $\% 73,2$ oranında çok iyi ve iyi şeklinde cevap vermişlerdir. Bilindiği üzere çekicilikler insanları kendilerine çekebilir ancak, hizmetin kalitesini ve memnuniyeti belirleyen en önemli bileşen insan faktörüdür. Şüphesiz bu noktada konukseverlik önemli bir değişken olarak karşımıza 
çıkmaktadır. Ancak bu konuda dört ilin tamamı kendilerini az ya da çok konuksever görmekteler. Örneğin Van'da deneklerin \% 87,3'ü çok iyi ve iyi şıkkını işaretlerlerken Muş'ta bu oran çok iyi ve iyi de \% 98,5'e çıkmaktadır. Aynı şekilde Hakkâri'de çok iyi ve iyi diyenlerin oranı \% 93,3 iken Bitlis'te bu oran çok iyi ve iyi de \% 98,4'e kadar çıkabilmektedir. Anlaşılan bu soruda duygusallık ve Anadolu insanı olmanın getirdiği değerler baskın gelmiştir.

Kitle turizminden uzak olan iç bölgelerde turizmin temel çekim elemanlarının başında doğal değerler gelmektedir. Doğal çevrenin çekim değerinin yüksek olması turistlerin o bölgeyi ziyaret etmesinde önemli bir motivasyon nedenidir. Bu anlamda yöneltilen doğal çevrenin güzelliği sorusuna Bitlis'teki deneklerin \% 76,6'sı çok iyi ve iyi cevabını verirken, Van \% 88,7, Muş \%73,8 ve Hakkari \% 73,3 şeklinde cevap vermişlerdir. İşletmelerde çalışan ya da yönetici pozisyonunda olan insanların müşteriler ödedikleri paranın karşılığını alıyorlar mı şeklindeki soruya verecekleri cevap oldukça önemlidir. Zira bu soru içerisinde bir parça soru işaretleri barındırıyordu. Bütün işletmelerin her ne sebeple olursa olsun kaliteli hizmet verdik şeklinde cevap verecekleri bekleniyordu. Ancak sonuçlar beklentileri boşa çıkaracak objektif bir yaklaşımın ürünüydüler. Her ne kadar Van bu konuda oldukça iyimser (\% 50,7 iyi) bir cevap verse de 4 ilin tamamı büyük ölçüde çok iyi ve çok kötü şıklardan oldukça uzak durmuşlardı. Ağırlıklı olarak fikrim yok ve kötü şıkları ön plana çıkmıştır. Örneğin, Bitlis'te birinci şık \% 45,3 ile kötü, Hakkari'de \% 36,7 ile fikrim yok ve Muş'ta \%38,5 ile kötü birinci şık olmuştur.

Yukarıda da ifade edildiği üzere araştırma temelde karşılaştırmanın yapıldığı iller üzerinden gerçekleştirilmekte ve her ilin kendisini bu iller üzerinden tanımladığı ve değerlendirdiği unutulmamalıdır. Bununla birlikte anket değerlendirmelerinde bazı sorular muhtemel rakipler ya da aynı düzeyde iller üzerinden gerçekleştirilirken Van'da bu durum biraz farklılaşmaktadır. Şöyle ki, Van hariç diğer üç il daha düşük yoğunluklu turizm hareketlerinin yaşandığı illeri kendilerine rakip olarak seçerlerken, Van daha çok turistik ürün ve turizm geçmişine sahip olması nedeniyle Trabzon, Kayseri, Diyarbakır ve Antep gibi güçlü markaları kendisine rakip olarak görmektedir. Buna rağmen Van diğer birçok parametrede olduğu gibi hijyen ve temizlik konusunda da rekabet edebilir olduğunu ifade etmektedir. Örneğin hijyen ve temizliğin kalitesi konusunda yöneltilen soruya Van'dan katılan denekler \% 67,6 oranında çok iyi ve iyi şıkkını işaretlerlerken, Muş'tan katılanlar \% 26,2, Hakkari'de \% 21,7 ve Bitlis'te \% 29,7 olmuştur. Benzer bir sonuç yiyecek ve içecek kalitesi konusunda da ortaya çıkmaktadır. Örneğin Van'daki deneklerin \% 78,9'u çok iyi ve iyi şeklinde soruya cevap verirlerken Muş'ta \% 41,5, Hakkâri'de \% 43,3 ve Bitlis'te \% 46,9 şeklinde gerçekleşmiştir.

Bir kentin ekonomik kalkınmasında ilk üç araçtan biri turizm ise o kentin turizme konu olma şekli ve mevcut arz kaynaklarının rekabet edebilme düzeyi nedir sorularına net bir şekilde cevap vermesi gerekmektedir. $\mathrm{Bu}$ anlamda rekabet edebilmenin en önemli bileşenlerinden birisinin de konaklama tesislerinin kalite ve standartlarıyla ilgilidir. Bu kapsamda deneklere yöneltilen bu soruya verilen cevaplar sırasıyla şu şekildedir. Van'dan katılan deneklerin \% 74,6'sı tesislerin kalite ve 
standardının çok iyi ve iyi olduğunu düşünürken, Muş'tan katılanlar \% 33,8, Hakkâri'den katılanlar \% 38,3 ve Bitlis'ten katılanların ise \% 15,6'sı çok iyi ve iyi olduklarını düşünüyorlar. Görüldüğü üzere Van hariç diğer üç ilden ankete katılanlar mevcut konaklama tesislerinin rekabet etmede yeterli olmadığını düşünüyor. Zira benzer sonuçlar gece yaşantısı ve eğlence olanakları konusunda da kendini göstermektedir. Şöyle ki, Van'dan araştırmaya katılan deneklerin gece yaşantısı ve eğlence olanakları sorusuna çok iyi ve iyi diyenlerin oranı \% 47,9 iken Muş \% 33,8, Hakkâri \% 8,3 ve Bitlis \% 4,7 ye kadar düşmüştür.

Gece yaşamı bir tarafa bırakılırsa sportif aktivite ve alışveriş imkânları belli ölçüde de olsa eğlence olanaklarına dâhil edilebilir. Zira birçok turist için günlük spor yapma ve alışveriş oldukça keyif verici bir etkinlik olabilmektedir. Bu anlamda deneklerin sportif aktivite ve alışveriş imkânı sorularına verdikleri cevaplar oldukça ilgi çekicidir. Şöyle ki, deneklerin sportif aktivite imkânlarının yeterliliği sorusuna verdikleri cevaplar Van dâhil olmak üzere dört ilde de kötü ve çok kötü seçenekleri belirleyici olmuştur. Örneğin Van'da kötü tek başına \% 45,1 iken Bitlis'te kötü tek başına \% 79,7, Hakkâri'de Çok kötü-kötü \%74 ve Muş'ta çok kötü-kötü \%75,4 şeklindedir. Buna karşın alışveriş imkânları konusunda Van diğer üç ilden ayrışmaktadır. Van'da deneklerin \% 50'den fazlası iyi olduğunu düşündügü alışveriş imkânı diğer üç ilde kötü ve çok kötü (üç ilin oranı \% 85'lerin üzerinde) şeklinde kabul edilmektedir.

Seçilmiş illere göre rekabet etme düzeylerinin belirlenmesi sürecinde önemli değişkenlerden birinin de sağlık hizmetleri olduğu kabul edilmektedir. Bu anlamda genel sağlık hizmetleri ve çocuk sağlığı hizmetlerinde kalitenin ne olduğuna ilişkin sorulan iki soruya deneklerin verdikleri cevaplar maalesef oldukça düşündürücüdür. Zira Muş ve Hakkâri her iki soruya da oldukça yüksek oranlarda olumsuz cevaplar vermişlerdir. Örneğin Hakkari'den ankete katılan denekler sağlık hizmetlerindeki kaliteyi \% 76.7 oranında kötü ve çok kötü şeklinde cevap verirlerken, çocuk sağlı̆̆ında çok kötü ve kötü diyenlerin oranı \%96.6'ya kadar yükselmektedir. Van ve Bitlis'in diğer iki ile oranla görece daha iyi durumda olmalarına karşın seçilmiş illerle rekabet edebilme noktasında yeterli olmadıkları anlaşılmaktadır.

Kentlerin turizme konu olması ve bir şekilde pazarlanabilmesi için en önemli bileşenlerden birinin kentsel altyapı olduğu genel kabul gören yaklaşımlardan biridir. $\mathrm{Bu}$ altyapılardan biri ve belki de turizm adına en önemlisi yerel ulaşım ağı ve kalitesidir. Bu soruya Van'dan ankete katılan denekler (\% 66.2 iyi ve çok iyi) hariç diğer üç ildeki denekler oranlar farklılaşsa da ( Hakkari \% 88.6 kötü ve çok kötü) rekabet etme düzeyi açısından kötü ve çok kötü seçeneklerini işaretlemişlerdir. Buna karşın iletişim ağının kalitesi ve bankacılık hizmetlerinin kalitesi noktasında bütün illerin rekabet edebilir düzeyde oldukları anlaşılmaktadır. Ancak bu noktada üzerinde durulması gereken sorulardan birisinin de ulaşılabilirlik ile ilgili olduğu anlaşılmaktadır. Diğer birçok soruda olduğu gibi Van'dan katılan denekler bu soruya da olumlu cevap vermekteler ve (\% 83,1 çok iyi-iyi) Van'ın ulaş1labilir olduğunu ifade etmektedirler. Rekabet edebileceklerini düşünen Vanlı deneklerin aksine Bitlis'ten 
katılan deneklerden çok iyi ve iyi diyenlerin oranı \% 28,1 iken Hakkari'de bu oran \% 26.7'ye kadar düşmektedir.

Şüphesiz her ilin turizme konu olma şekli büyük ölçüde turizm değerleriyle doğrudan ilişkilidir. Dolayısıyla çekicilikler noktasında yeterli olan iller benzer ürünleri pazarlayan destinasyonlara oranla daha avantajlı duruma geçebilmektedir. Araştırmaya konu olan TRB 2 Bölgesinde temel çekicilikler ağırlıklı olarak kültür ve tarihi kaynaklar noktasında ortaya çıkmaktadır. Dolayısıyla bu kaynakların yeterliliği ve turist çekme potansiyellerinin seçilmiş illerle kıyaslanması ve rekabet edebilirlik düzeylerinin ölçülmesi gerekmektedir. Bu anlamda deneklere iki soru yöneltilmiştir. Bunlardan ilki kültürel zenginlikle ilgili olandır. Bu soruya Van'dan katılan denekler açık ara ( \% 81.7 iyi ve çok iyi) yeterli olduklarını düşünürken, onu sırasıyla Bitlis (\% 65.6), Hakkari (\% 46.7) ve Muş (\% 46.2) takip etmektedir. Kültürel zenginlik yanında tarihi zenginlik noktasında da Van'dan katılan denekler \% 90 oranında iyi ve çok iyi olduklarını düşünürlerken, onu sırasıyla Bitlis \%65.6, Hakkari \%48.3, Muş \%46.2 şeklinde takip etmektedir. Tarihi ve kültürel çekiciliklerin yanı sıra diğer çekicilikleri de içeren bir soru deneklere yöneltilmiş ve toplam çekiciliklerin rekabet etmede il için ne anlam taşıdığı anlaşılmaya çalışılmıştır. Bu anlamda toplam çekiciliklerin seçilmiş illere göre ne anlam ifade ettiği sorusuna denekler sırasıyla şu cevapları vermişlerdir. Van'dan katılan denekler \% 81.7 oranında iyi ve çok iyi şıklarını işaretlerlerken, Bitlis \%75, Muş \%72.3 ve Hakkari \%26.7 şeklinde cevap vermişlerdir. Diğer üç ilin aksine Hakkâri'nin olduk karamsar ve rekabet edebilme noktasından uzak olması aslında büyük ölçüde mevcut turist hareketi ve bu hareketin yarattığı ilişkilerle alakalıdır. Şöyle ki, bölgeyi ziyaret eden turistlerin büyük çoğunluğunun İranlı olmaları ve görüldüğü kadarıyla İranlı turistlerin alış veriş ve eğlenceye dönük çekicilikleri talep etmeleri bu sonucu doğurmuştur.

Her türlü ürünün pazarlanmasında tanıtım ve reklam politikalarının etkinliği en önemli değişkenlerdendir. Dolayısıyla turizme konu olmak isteyen her bölge bir şekilde tanıtım yapmalı ve farklı reklam politikaları izlemelidirler. Yöneltilen bu soruya dört ilden ankete katılan deneklerin büyük kısmı çok kötü ve kötü şıkkını işaretlemişlerdir. Hatta bu oran Bitlis'te \% 10.9'a kadar düşmektedir.

Rekabet düzeyini belirlemede öncü değişkenlerden biride ilin kurumsal olarak ulusal ve bölgesel olumsuzluklara verdiği tepkilerdir. Bu anlamda rekabet düzeylerini ölçmek için dört farklı soru yöneltilmiştir. Bunlar, ekonomik krizler, politik istikrarsızlıklar, doğal afetler ve savaş - terör olaylarıdır. Bu sorulardan ilki olan ekonomik krizlerde TRB2 Bölgesindeki illerin rekabet etme düzeylerinin oldukça düşük olduğu görülmektedir. Zira olası bir kriz döneminde oldukça kırılgan olan ekonomik dengelerinin seçilmiş illere göre çok daha hassas olduğunu düşünmekteler. Öyle ki araştırmaya konu olan dört ilde de bu soruya kötü ve çok kötü diyenlerin oranı \% 70'lerin (Hakkari \% 87.5) üzerindedir. Ekonomik krizlerdeki hassasiyet politik istikrarsızlıkta da kendini göstermektedir. Bütün illerin çok kötü ve kötü oldukları bu kategoride en yüksek olumsuz görüşü \% 85.9 ile Bitlis göstermiştir. 
Ulusal ölçüde değerlendirilen yukarıdaki iki değişkenin aksine bölgesel düzeyde gerçekleşen olumsuzluk rekabet düzeyini belirlemede daha gerçekçi olacaktır. Bu bağlamda ilk soru doğal afetlere ilişkin olmuştur. Bu soruya Van \%79 oranında çok kötü ve kötü cevabını verirken Muş \% 73.9, Bitlis \% 68.7 ve Hakkari \% 63.4 şeklinde cevap vermiştir. Görüldüğü üzere doğal afeti en ciddi bir tehdit olarak gören il Van ilidir. Şüphesiz bunda 2011 Van depremlerinin rolü oldukça büyüktür. Bölge açısından düşünüldüğünde en ciddi sorunlardan birinin de savaş ve terörle ilgili olduğu muhakkaktır. Savaş ve terörün rekabet etme de nasıl bir değişken olduğu sorusuna denekler oldukça yüksek oranlarda çok kötü ve kötü cevabını vermişlerdir. $\mathrm{Bu}$ soruya en yüksek oranda olumsuz yaklaşan ve rekabet etmede önemli bir sorun olarak gören şehir Van olmuştur. Van'dan katılan deneklerin \%81.7'si çok kötü ve kötü şıkkını işaretlemişlerdir. Bu şehri sırasıyla, Muş \% 80, Hakkari \% 80 ve Bitlis \% 68.8 (kötü ve çok kötü) oranıla takip etmiştir.

Türkiye seksen milyon nüfusuyla çok nüfuslu ülkeler kategorisinde değerlendirilebilecek bir ülkedir. Hem sayıca büyük bir ülke olma hem de uzun yıllardır devam eden merkezi yönetim alışkanlıkları yıllar içinde devasa bir bürokrasi geleneğinin oluşmasına neden olmuştur. Dolayısıyla işletmelerin karar alma ve uygulamalarında bürokrasi ciddi bir engel olarak karşılarına çıkmaktadır. Ancak bölgesel düzeyde farklı uygulamalar bazen çok daha ciddi dezavantaj sağlayabilmektedir. Bu anlamda TRB2 Bölgesindeki işletmelerin bu sorun karşısında kendilerini karşılaştırıldıkları illere göre konumlamaları rekabet edebilirlik açısından önemlidir. Devletin ve bürokrasinin rekabet etme noktasında sizleri destekleme düzeyi nedir sorusuna Van'dan katılan deneklerin birinci tercihi fikrim yok (\% 36.6) şeklinde olurken, Bitlis ve Hakkari \% 69 ile kötü ve çok kötü, Muş'ta ise iyi ve kötü dengeli bir şekilde dağılmıştır.

Rekabet edebilmede kentin, bölgenin ve daha büyük ölçüde ülkenin pozisyonu ve mevcut konjonktür rekabet edebilme kapasitenizi belirlese de işletmelerin pazarlama ve rekabet stratejileri de en az onlar kadar belirleyicidir. Bu bağlamda deneklere yöneltilen sorulardan ilki pazarlama stratejilerinin olmasına ilişkindir. Bu soruya Van'dan katılan denekler \% 76.6 ve Muş'tan katılanlar \% 67.7 oranında iyi ve çok iyi şeklinde cevap verirlerken, Hakkari \% 45, Bitlis \% 26.6 şeklinde olumlu cevap vermişlerdir. Hakkâri ve Bitlis'in olumsuz tavrı bir sonraki soru olan işletmenin rekabet stratejisi konusunda da devam etmiştir. Bu soruya da Van ve Muş olumlu yaklaşırlarken diğer iki il \% 20'ler düzeyinde olumlu yaklaşmışlardır. Diğer bir ifadeyle Van ve Muş illerinde yer alan işletmeler veya diğer bir ifadeyle ankete katılan denekler, bir pazarlama ve rekabet stratejisine sahip olduklarını ve bu stratejilerinin rakip illerle kıyaslandığında onlara rekabet edebilecek bir yapı kazandırdığını düşünmektedirler.

Turizm uluslararası boyutu olan ve oldukçada kırılgan bir yapıya sahiptir. Dolayısıyla uluslararası turizme konu olmak ve yatırımcı çekmenin yanı sıra yerel, ulusal ve uluslararası durumdan kaynaklanan sorunlarla baş edebilmek için teşvik politikalarına ihtiyaç vardır. Turizme konu olacak alanlar özellikle turizm altyapısı konusunda yeterli değilse, bu durumda teşvik programları büyük ölçüde bir 
zorunluluk halini almaktadır. Tam da bu nokta da TRB2 Bölgesin teşvike büyük ölçüde ihtiyaç duyduğunu ifade etmek gerekmektedir. Bu bağlamda Turizme özgü maliyet ve teşvik politikalarının olması rekabet açısından ne anlam ifade ediyor şeklinde yöneltilen soruya Van'dan katılan denekler \% 62.2 ile olumlu yaklaşırlarken Bitlis, Muş ve Hakkari olumsuz yaklaşmışlardır. Diğer bir ifadeyle mevcut maliyet ve teşvik politikalarının onları seçili illerle kıyaslandığında desteklemediğini ifade etmişlerdir.

Bu bölümde açıklığa kavuşturulması geren sorulardan bir tanesinin de seçmiş olduğunuz ile göre "ulusal turizmdeki rekabet düzeyini nasıl görüyorsunuz" sorusudur. Zira bu soru kişilerin genel eğilimlerini göstermesi açısından anlamlı olduğu gibi, nerede oldukları sorusuna da belli ölçüde cevap vermiş sayılacaktır. Bu bağlamda verilen cevaplar dört il içinde çok parlak sayılmaz. Buna karşın Van için ayrı bir parantez açmak gerekmektedir. Çünkü Van'dan ankete katılan denekler büyük ölçüde fikrim yok demelerine karşın olumlu yaklaşanların sayısı \% 40'lar civarındadır. Oysa diğer üç il \%18 ile \% 20'ler civarında seyretmektedirler. Dahası üç il bu konuda kararsız değiller. Diğer bir ifadeyle rekabet etme düzeylerini düşük görüyorlar.

Rekabet etmede en önemli değişken ve turizm arzının temel parametrelerinden biri hiç şüphe yok ki ulaşımdır. Özellikle ulaşımın şekli ve kalitesi seyahate çıkan turistlerin karar verme süreçlerinde teşvik edici veya caydırıcı olabilir. Bu bağlamada TRB2 illerinin üçünde hava alanı mevcuttur. Bunlardan en donanımlı olanı Van Ferit Melen Hava alanıdır. Dolayısıyla Bitlis hariç diğer üç il turizmin temel ulaşım sitemi olan hava ulaşımına sahiplerdir. Ancak temel sorun bu hava alanlarının kullanım düzeyi ile ilgilidir. Bu kapsamda deneklere yönelttiğimiz soruya Muş \% 65.7 iyi ve çok iyi cevabını verirken, Hakkari \%68.2, Van 65.7 oranlarında iyi ve çok iyi cevaplarını vermişlerdir.

Son olarak Van Gölü'nün varlığından kaynaklanan iki soru ve ilinizin turizmi ile ilgili görüşlerinizi kısa olarak belirtiniz şeklinde açık uçlu bir soru yöneltilmiştir. İl iki soru yalnızca Van ve Bitlis'ten ankete katılan deneklerin cevap vermesi istenmiştir. $\mathrm{Bu}$ sorulardan ilki "Van Gölünün varlığı", diğeri ise "göl kıyısındaki kumsalların kalitesi" olmuştur. Bu sorulardan ilkine her iki ilden katılan denekler \% 96 oranında olumlu yaklaşmalarına karşın, ikinci soruya her iki ilde \% 80 civarında olumsuz cevap vermişlerdir.

\section{SONUÇ}

Bitlis, Hakkari, Muş ve Van illerinden oluşan TRB2 bölgesi, kültürel mirası, yer altı ve yer üstü kaynakları, Van Gölü'nün bölgede yer alması ve sınır ticareti potansiyelinin olması gibi faktörlerden dolayı ülke ekonomisinde önemli bir yere sahip olmasına rağmen sosyo-gelişmişlik ve turizm göstergeleri açısından istenilen noktada değildir. TRB2 bölgesinin rekabet düzeyini ölçmeyi amaçlayan ve neredeyse dört ildeki bütün işletmeleri kapsayacak şekilde yapılan bu çalışma, bölgenin rekabet edilebilirliği ile ilgili oldukça anlamlı sonuçlar ortaya konmuştur.

Araştırmaya konu olan TRB2 bölgesinde ağırlıklı olarak kültür, tarih, sağlık, kış ve belli ölçüde ekoturizm pazarlanmaktadır. Ancak son yıllarda özellikle İran'lı 
turistlerin etkin şekilde bölge illerini ziyaret etmesi alışveriş turizmini de gündeme getirmiştir. Dolayısıyla TRB2 Bölgesindeki illerde hizmet veren turizm işletmeleri hem nitelikli veya diğer bir ifadeyle seçkin turistlere hem de ekonomik kaygıların ön plana çıktığı İran'lı turistlere hizmet vermektedir. Bir tarafta kültür, tarih ve doğal kaynakların pazarlandığı ve bu çerçevede hazırlanan yüksek maliyetli bir konsept, diğer tarafta en uygun şartlarda günübirlik veya birkaç günlük turistler için hazırlanan düşük maliyetli konsept, bu iki temel yaklaşım işletmelerin üzerinde en çok durdukları konulardır. Tamda bu noktadan hareketle TRB2 Bölgesindeki illerin seçilmiş illere göre rekabet edebilirlik düzeylerinin tanımlanması gerekmektedir. Zira benzer turizm çeşitlerini pazarlayan seçilmiş iller düzeyinde turizm işletmelerinin ne anlam ifade ettiği araştırma bulgularında net bir şekilde ortaya çıkmıştır.

Araştırma bulguları kısmında da ifade edildiği gibi kıyaslama için 10 il seçilmiştir. Ancak denekler bu illerden hangilerini ziyaret etmiş iseler ona göre bir kıyaslama gerçekleştireceklerdir. Bu bağlamda araştırmada elde edilen ilk somut sonuç katılımcıların sorulara vermiş oldukları cevaplar ile turizm geçmişleri arasında doğru bir ilişkinin olduğu bilgisidir. Araştırmaya konu olan dört il turizm işletmelerinin büyüklüğü, hizmet verdikleri turist sayısı ve yelpazesi, turizm geçmişi, turizm arz kaynakları ve diğer birçok değişken açısından farklılık göstermektedirler. Dolayısıyla turizm işletmelerinin kapasiteleri ve doğal olarak katılımcıların sorulara vermiş oldukları cevaplar farklılık arz etmektedir. Bu bağlamda rekabet düzeyine ilişkin Van'dan ankete katılan deneklerin sorulara verdikleri cevaplar Bitlis, Hakkari ve Muş'tan büyük ölçüde ayrışmaktadır. Van'dan katılan deneklerde ciddi bir özgüven ve geleceğe ilişkin beklenti hakimken, Hakkari'den katılanlarda tam tersi bir durum söz konusudur. Dolayısıyla denilebilir ki, rekabet edilebilirlik düzeyi en yüksek il Van'dır. Bu durum turizm göstergeleri açısından da kendini göstermektedir. Van'da çalışmaya katılan denekler, kültürel zenginlik, doğal güzellik, kentin alt yapısı gibi bir çok açıdan, diğer illerle rekabet edebilecek durumda olduklarını belirtmişlerdir. Çalışma da ayrıca, rekabet düzeyi en düşük ilin Hakkari olduğu anlaşılmaktadır.

Çalışma sonuçları genel olarak değerlendirildiğinde, bölgenin turizm açısından rekabet edilebilirlik düzeyi, kültürel zenginlik ve doğal güzellikler açısından diğer illere göre rekabet edilebilir düzeyde olsa da, bazı temel alanlarda problemleri bulunmaktadır. Bunların en başında işletmelerdeki çalışanların eğitim düzeyi ve turizm eğitimine ilişkindir. Çalışanların eğitim düzeylerinin yeterli olmaması veya turizm eğitimi alan kişilerin sayıca az olması sektörde verilen hizmet kalitesini olumsuz yönde etkilemektedir. Bu bağlamda, hizmet kalitesi ile müşteri memnuniyetinin yükseltilmesi ve rekabet gücü elde edilmesi için turizm sektöründe turizm eğitimi almış nitelikli işgücüne ihtiyaç duyulduğu anlaşılmaktadır.

Bölgenin rekabet edilebilirliğini olumsuz etkileyen diğer önemli bir faktör ise tanıtım ve reklam politikalarının doğru ve etkin kullanılmaması ve aynı zamanda imaj sorunudur. Yerel ve ulusal medyada bölgeyle ilgili çıan olumsuz haberler, bölgenin güvenli olmadığı algısı bölgenin turizm açısından rekabet edilebilirliğine ciddi anlamda zarar vermektedir. Bundan dolayı anketi cevaplayan katılımcıların çoğu 
tanıtım ve reklam politikaları ile ilgi soruya kötü ve çok kötü olarak ifade etmektedirler.

Rekabet düzeyini belirlemede önemli bir değişken ise, bölgenin ekonomik krizler, politik istikrarsızlıklar, doğal afetler ve savaş - terör olayları gibi bölgesel veya ulusal ölçekte yaşanan olumsuz olaylardan etkilenme derecesidir. TRB2 bölgesi maalesef bu durumdan en çok etkilenen bölgelerden biridir. 2011'de yaşanan Van depremi bu durumu daha da pekiştirmiştir. Ayrıca çalışmaya katılan deneklerin çoğu bölgenin rekabet edilebilirliği açısından temel problemin savaş ve terör olduğuna işaret etmektedir.

Ulusal bir ağın parçası olan konaklama tesisleri hariç, dört ilde de katılımcıların önemli bir kısmı işletmelerinin bir pazarlama ve rekabet stratejilerinin olmadığını düşünüyor. Dört ilde de ortak olan bir diğer cevap ise misafirperverlik vurgusudur. Bütün iller bu soruda en iyi olduklarını ifade etmek için adeta yarışmış durumdalar. Ayrıca, Van hariç diğer üç il turizme hizmet verme noktasında henüz yeterli olmadıklarını ve bu konuda yol kat etmeleri gerektiğini biliyorlar. Ancak mevcut turizm çeşidi ve turist pazarı başta kar marjlarını düşürdüğü ve doluluk sorunları yaşattığı için mücadele etmede geri durmalarına ve başta kalifiye olmak üzere yeterli eleman çalıştırmamalarına neden olmaktadır.

\section{KAYNAKÇA}

Aktan C. C. ve Vural İ. Y, (2004) "Yeni Ekonomi ve Rekabet", TiSK Yayınları, Yayın No:253, Ankara, 2004.

Alaeddinoğlu, F. ve Samırkaş, M. (2014), “Van İli Turizminin Rekabet Gücü Üzerine Bir Alan Araştırması ",Ed: Nazmi Kozak ve Osman Eralp, III. Disiplinlerarası Turizm Araştırmaları Kongresi, Detay Yayınları, Kuşadası, Aydın.

Bahar, O. (2004). Türkiye'de Turizm Sektörünün Rekabet Gücü Analizi Üzerine Bir Alan Araştırması: Muğla Örneği (Basılmamış Doktora Tezi), Muğla Üniversitesi S.B.E., İktisat Anabilim Dalı.

Bahar, O. ve Kozak, M. (2012), Turizm ve Rekabet, Anakara: Detay Yayıncllı.

Boschma, R. A. (2004) "Competitiveness of Regions from an Evolutionary Perspective", Regional Studies, Vol.38.9, pp.1001-1014.

Costa, C., 'An Emerging Tourism Planning Paradigm? A Comparative Analysis between Town and Tourism Planning', 2001, International Journal of Tourism Research, vol. 3, no. 6, pp. 425-441.

Crouch, G. I., Ritchie, J. R. B., (1999) "Tourism, Competitiveness and Societal Prosperity", Journal of Business Research 44, pp. 137-152.

Çapoğlu, G. (1993), "Rekabet Kavramı ve Rekabeti Koruma Yasa Tasarısı", Türkiye İktisat Dergisi, Yıl: 5 Sayı:14.

DAKA, (2011). TRB2 Bölgesi Mevcut Durum Analizi Ekonomik Yapı, Van: DAKA.

DAKA, (2013). TRB2 Bölgesi Mevcut Durum Analizleri, Van: DAKA.

DAKA, (2014). TRB2 Bölgesi 2011-2013 Bölge Planı (Bitlis-Hakkari-Muş ve Van) Van: DAKA. 
DAKA. (2010). Doğu Anadolu Kalkınma Ajansı Ön Bölgesel Gelişme Planı, www.daka.org.tr (E. $\mathrm{T}: 24.06 .2014)$.

Düzgün, R. (2007). “Türkiye'nin Uluslararası Rekabet Gücü: Çok Değişkenli İstatistiksel Bir Analiz", Sosyal Bilimler Enstitüsü Dergisi, Say: 23: 2, ss.421-440.

Dwyer, L and Kim, C. (2003). Destination Competitiveness Determinants and Indicators, Current Issues in Tourism, 6(5): 369-414.

Gürsoy, D., Baloğlu, Ş. ve Millar, M. (2008) "A Competitiveness Analysis of Middle Eastern Countries" Paper presented at the European Council for Hotel, Restaurant, and Institutional Education Conference, Dubai, United Arab Emirates.

Lai, K., Li, Y. and Feng, X., 'Gap between Tourism Planning and Implementation: A Case of China', 2006, Tourism Management, vol. 27, no. 6, pp. 1171-1180.

Prideaux, B (2000). "The Role of the Transport System in Destination Development", Tourism Management, 21 (1), pp.53-63.

Samırkaş, M. (2014) “Turizm Sektörünün Ekonomi İçindeki Yeri ve Önemi: Van İli Bağlamında Bir Değerlendirme Van Turizmi Geleceğini Arıyor Çalıştay Kitabı İçinde, Yayım: DAKA, ss.96-109.

Samırkaş, M. ve Bahar, O. (2011). “Turizm Sektörünün Bölgelerarası Gelişmişlik Farklılıklarını Gidermedeki Etkisi: Yakınsama Modeli" Finans Politik ve Ekonomik Yorumlar Dergisi, Cilt 48, Say1 557, ss.85-98.

Sharpley, R., 'Planning for Tourism: The Case of Dubai', 2008, Tourism and Hospitality Planning $\mathcal{E}$ Development, vol. 5, no. 1, pp. 13-30.

Timurçin, D. (2010), “Türkiye'de KOBİ'lerin Rekabet Gücü ve Rekabet Üstünlüğü Sağlamada Kümelenmenin Etkisi", (Basılmamış Doktora Tezi), İstanbul Üniversitesi Sosyal Bilimler Enstitüsü İktisat Anabilim Dalı, İstanbul.

ww.turizm.gov.tr (02.07.2017)

www.dpt.gov.tr, (06.08.2017)

www.tuik.gov.tr, (24.07.2017) 